\title{
Emerging Heating Technologies in Dairy, Eggs, and Meat Products Processing and Preservation
}

\author{
Leidiane AA Menezes* \\ Department of Food Science and Technology, Federal University of Santa Catarina, Brazil
}

Submission: June 08, 2019; Published: June 21, 2019

*Corresponding author: Leidiane AA Menezes, Department of Food Science and Technology, Federal University of Santa Catarina, 88034-001, Florianopolis, SC, Brazil

\section{Mini Review}

The microbial safety of the product, dairy, meat and eggs products continues is a constant concern of the food industry. The foodborne illness remains serious public-health concern. At the same time, the market for animal products is becoming more dynamic and global. In recent years, many new preservation methods have developed to extend the quality and shelf-life, minimize risk, protect the environment, and improve functional, sensory, and nutritional properties [1,2]. In recent decades, many new preservation methods have been developed and improved in order to ensure the sensorial and nutritional quality of products, increase their shelf-life, reduce the risk of disease, and minimize environmental impacts. Some of the emerging technologies are already deployed in industries and others are still waiting to be implemented [3]. The emerging technologies are classified into thermal and non-thermal methods. Regarding the thermal methods, we will deal with the ohmic heating $(\mathrm{OH})$, radio frequency (RF) and microwave heating (MH). In traditional heat processing techniques, heating occurs by the contact of the food with a heated surface, and the heat is transferred by conduction and convection. In contrast, in the new heating technologies, called volumetric heating, the heat is generated throughout the whole volume of the material, by the use of electromagnetic fields. The $\mathrm{OH}$ is based on passing an alternating current $(50 \mathrm{~Hz}$ to $100 \mathrm{kHz}$ ) through the product. Radio frequency and microwave heating use different frequencies, below $300 \mathrm{MHz}$ and above $300 \mathrm{MHz}$, respectively. Radio frequency and microwave heating (known as dielectric heating $[4,5]$.

$\mathrm{OH}$ can be applied to a wide variety of foods, including liquids and solids [6], and mixtures. The technology has been successfully used to produce liquid egg products, solving troubles with the temperature sensitive nature of the eggs and the changes in the rheology after heating. $\mathrm{OH}$ has also been applied in dairy and meat products, such as sausages, hamburgers and ham [7]. In general the $\mathrm{OH}$ has shown good results regarding the inactivation of pathogenic microorganisms such as Escherichia coli, Streptococcus thermophilus, and Listeria monocytogenes. However, the efficiency of the microbiological load reduction depends on the time/temperature applied, and the characteristics of the product, for example, foods with more than $3 \%$ fat may exert a protective effect on the cells. Regarding the implications in sensorial quality, there has been reported little or no changes in the texture and taste of eggs, milk, meat and their products [4-6]. In the case of dielectric heating techniques, applications include cooking of bacon slices for use as food topping, RF defrosting of meat, chicken and fish defrost, microwave defrosting and tempering meats and butter, microwave pasteurizing of ready meals and packaged products [7].

The major advantages of $\mathrm{OH}$ are the reduction of the thermal degradation (and consequently the smaller alteration of the nutritional and sensorial characteristics of the food), low maintenance and minimal fouling of surfaces, applicable for high viscosity products, working temperatures $>150{ }^{\circ} \mathrm{C}$, faster and uniform heating. On the other hand, the limitations: only feasible for products pumpable and with a suitable electrical conductivity, design difficult for a range of products and cost of electrical energy. In relation to $\mathrm{RF}$ and $\mathrm{MH}$, the advantages presented are reduced processing times, improved product quality, higher energy efficiency, allow new product development, for example, alternatives to frying, obtaining products with high added value. The main disadvantages are the high cost of the equipment, dependence of the dielectric properties of the food $[6,7]$.

So if these technologies appear to have more advantages than limitations, what are the reasons why the industry has not yet fully adhered to them? [6] drew a very interesting picture of the emerging technologies in 31 countries on all continents. Among the new thermal technologies, $\mathrm{MH}$ has been suggested as the best known, most promising and the most interesting for the industry. The greatest difficulties for implementation were reported as the high cost of equipment, product price increase, narrow range of equipment available, the risk involved, lack of regulation, and the clear benefits of using novel technology. Extension of shelf life, preservation, pasteurization and better quality and added value were the most interesting purposes. The microwave technology scored well for implementation or potential implementation for 
dairy, meat and fish/sea food and poultry sectors, $\mathrm{OH}$ for the dairy sector. Given that, the incorporation of these new methods depends mainly on financial issues the level at which the companies know and trust the new methods. I $\mathrm{n}$ any case, there is an increasing trend for adhesion for the next 5 or 10 years.

\section{Conflicts of Interest}

Declare if any economic interest or any conflict of interest exists.

\section{References}

1. Cummins EJ, Lyng JG (2017) Emerging technologies in meat processing.

2. Mukhopadhyay S, Ukuku DO (2018) ScienceDirect the role of emerging technologies to ensure the microbial safety of fresh produce, milk and eggs \$. Current Opinion in Food Science 19: 145-154
3. Jermann C, Koutchma T, Margas E, Leadley C, Ros-polski V (2015) Mapping trends in novel and emerging food processing technologies around the world. Innovative Food Science and Emerging Technologies 31: 14-27.

4. Cappato LP, Ferreira MVS, Guimaraes JT, Portela JB, Costa ALR, et al. (2017) Ohmic heating in dairy processing: Relevant aspects for safety and quality. Trends in Food Science \& Technology 62: 104-112.

5. Smetana S, Terjung N, Aganovic K, Alahakoon AU, Oey I (2019) Emerging Technologies of Meat Processing. Sustainable Meat Production and Processing.

6. Jaeger H, Roth A, Toep S, Holzhauser T, Engel K, et al. (2016) Opinion on the use of ohmic heating for the treatment of foods. Trends in Food Science \& Technology 55: 84-97.

7. Maloney N, Harrison M (2016) Chapter 8 - Advanced Heating Technologies for Food Processing. Innovation and Future Trends in Food Manufacturing and Supply Chain Technologies.

\section{Your next submission with Juniper Publishers will reach you the below assets}

- Quality Editorial service

- Swift Peer Review

- Reprints availability

- E-prints Service

- Manuscript Podcast for convenient understanding

- Global attainment for your research

- Manuscript accessibility in different formats

( Pdf, E-pub, Full Text, Audio)

- Unceasing customer service

Track the below URL for one-step submission https://juniperpublishers.com/online-submission.php 